\title{
Pengaruh Frekuensi dan Periode Pemberian Pakan Terhadap Produksi Karkas Ayam Buras Super
}

\section{Effect of Frequency and Feeding Period on Carcass Production in Crossbred Native Chicken}

\author{
I. Darmawan*, E. Suprijatna dan U. Atmomarsono \\ Fakultas Peternakan dan Pertanian, Universitas Diponegoro, Semarang, 50275 \\ *E-mail: iwandarmawan077@gmail.com \\ (Diterima: 4 Oktober 2016; Disetujui: 7 Desember 2016)
}

\begin{abstract}
ABSTRAK
Penelitian ini bertujuan untuk mengetahui produksi karkas ayam buras super yang optimal dengan manajemen pemberian pakan yang berbeda. Materi yang digunakan adalah 252 ekor anak ayam buras super unsex umur 1 hari dengan bobot badan awal rata-rata 37,88 $\pm 1,89 \mathrm{~g}$. Ransum yang digunakan adalah ransum komersial. Rancangan percobaan yang digunakan adalah Split Plot Design dengan 4 ulangan sehingga terdapat 36 unit percobaan, tiap unit percobaan terdiri dari 7 ekor ayam. Split Plot Design terdiri dari main plot yaitu 3 taraf frekuensi pemberian pakan dan sub plot yaitu 3 taraf periode pemberian pakan. Data yang diperoleh dianalisis menggunakan sidik ragam dan uji $\mathrm{F}$ pada taraf $5 \%$. Hasil penelitian menunjukkan bahwa pengaruh interaksi antara frekuensi pemberian pakan dengan periode pemberian pakan tidak nyata $(\mathrm{p}>0,05)$, demikian pula masing-masing perlakuan tidak menunjukkan pengaruh yang nyata $(\mathrm{p}>0,05)$ terhadap produksi karkas ayam buras super. Kesimpulan dari penelitian ini adalah persentase karkas yang tinggi adalah tidak ada interaksi frekuensi pemberian pakan dan periode pemberian pakan terhadap produksi karkas.
\end{abstract}

Kata kunci: ayam buras super, produksi karkas, frekuensi, periode, pemberian pakan

\section{ABSTRACT}

The purpose of this study was to determine the optimalize of carcass production on crossbrednative chicken with different feeding management. The material were 252 unsex crossbred native chickens aged one day with around $37.88 \pm 1.89 \mathrm{~g}$. The ration was a commercial feed. The experimental design used in this research wasSplit Plot Design with 4 replications hence were 36 experimental units, and consists of 7 chickens. Split Plot Design consists of main plot which have 3 feeding frequency levels and sub plot which have 3 feeding periods stages offeeding. The data were analyzed by analysis of variance and $F$ at $5 \%$ level. The results showed that no interaction $(p>0.05)$ between feeding frequency and feeding periods, similrly the treatment were not significantly affect $(p>0.05)$ on carcass production in crossbred native chicken. The conclusion of this research is no interaction of feeding frequency and feeding period on carcass production in crossbred native chicken.

Keywords: crossbred native chicken, carcass production, frequency, time periods, feeding

\section{PENDAHULUAN}

Permintaan ayam buras sebagai ayam pedaging saat ini di Indonesia meningkat, tetapi belum bisa terpenuhi karena produktivitas dan laju pertumbuhan yang rendah. Ayam buras merupakan jenis unggas lokal Indonesia (Tamzil et al., 2015). Peningkatan mutu genetik diperlukan untuk meningkatkan produktivitas, salah satunya dengan cara menyilangkan ayam buras dengan ayam ras. Ayam buras persilangan bisa dipanen umur 50 - 60 hari lebih cepat, dengan bobot badan sekitar 0,7-0,85 kg (Muryanto et al., 2002).

Indonesia merupakan suatu negara yang memiliki iklim tropis. Temperatur lingkungan di Indonesia yang fluktuatif pada pagi, siang dan sore hari mempengaruhi kebutuhan energi ayam yang fluktuatif. Manajemen pemberian pakan diperlukan untuk mengatasi suhu yang 
berfluktuasi tersebut, karena dalam sehari ayam bisa mengalami heat stress dalam periode waktu tertentu. Heat stress yang dialami ayam selama 4 jam perhari mengakibatkan turunnya performans ayam (Sugito dan Dilema, 2009). Ayam yang berada dikondisi heat stress maka produktivitas dam pertumbuhannya akan turun. Kondisi Heat stress mempengaruhi bobot badan ayam, konsumsi pakan, proses metabolisme tubuh terganggu, kesehatan ayam dan laju pertumbuhan ayam menjadi turun (Li et al., 2015).

Salah satu cara untuk menghindari heat stress pada ayam yaitu memanajemen pemberian pakan dengan mengatur frekuensi pemberian pakan dan periode pemberian pakan. Berfluktuasinya suhu di pagi, siang, dan sore hari, maka perlu penyesuaian dengan cara mengatur frekuensi pemberian pakan 1 kali, 2 kali dan 3 kali dalam satu hari. Periode pemberian pakan yang dimaksud adalah waktu saat pagi hari dimana pada jam berapa ayam diberi pakan. Hal ini berkaitan dengan penggunaan energi pakan oleh ayam. Ayam yang berada pada kondisi lingkungan yang panas, mengakibatkan ayam terkena cekaman sehingga menurunkan laju pertumbuhan jaringan tubuh, karena energi ransum dipergunakan untuk melepaskan panas tubuhnya (Neves et al., 2014). Hasil penelitian Hasan et al. (2013) frekuensi pemberian pakan 2 kali, 3 kali dan 4 kali tidak berpengaruh nyata terhadap bobot akhir pada ayam pedaging. Tingkat pertumbuhan maksimal ayam terjadi pada kisaran suhu 10 $-22{ }^{\circ} \mathrm{C}$, sedangkan efisiensi pakan berkisar pada suhu $27{ }^{\circ} \mathrm{C}$, dan untuk kisaran nyaman tumbuh ayam pada suhu $18-22^{\circ} \mathrm{C}$ (Suganya et al., 2015).

Ayam yang mampu menggunakan energi secara efisien akan menghasilkan bobot hidup yang tinggi, sehingga menghasilkan bobot karkas yang tinggi juga, dengan demikian bahwa frekuensi dan periode pemberian waktu pada saat lingkungan nyaman akan memberikan keefisienan energi yang baik dalam menghasilkan produksi karkas. Oleh karena itu perlunya diteliti tentang manajemen pemberian pakan yang tepat pada aam buras super. Maka penelitian ini bertujuan untuk mengetahui pengaruh kombinasi antara frekuensi pemberian pakan dan periode pemberian pakan yang baik untuk pemeliharaan ayam buras super terhadap produksi karkas.

\section{METODE}

Materi yang digunakan dalam peneelitian adalah 252 ekor anak ayam buras super unsex berumur 1 hari dengan bobot badan awal rata-rata $37,88 \pm 1,89 \mathrm{~g}$. Kandang

Tabel 1. Kandungan nutrien ransum dalam \% kering udara.

\begin{tabular}{|c|c|c|}
\hline \multirow{2}{*}{ Kandungan Nutrien } & \multicolumn{2}{|c|}{ Ransum } \\
\hline & Starter & Finisher \\
\hline Protein Kasar (\%) ${ }^{1}$ & 21,02 & 20,44 \\
\hline Lemak Kasar $(\%)^{1}$ & 6,71 & 4,03 \\
\hline Serat Kasar $(\%)^{1}$ & 3,27 & 4,56 \\
\hline Kalsium $(\%)^{2}$ & 1,00 & 0,82 \\
\hline Fosfor $(\%)^{2}$ & 0,44 & 0,33 \\
\hline Kadar Air (\%) ${ }^{1}$ & 12,22 & 11,97 \\
\hline Kadar Abu (\%) ${ }^{1}$ & 6,96 & 7,01 \\
\hline Energi Metabolis $(\mathrm{kkal} / \mathrm{kg})^{3}$ & 2.759 & 2.601 \\
\hline
\end{tabular}

Keterangan :

${ }^{1}$ Hasil Analisis Proksimat di Laboratorium Ilmu Nutrisi dan Pakan, Fakultas Peternakan dan Pertanian, Universitas Diponegoro (2017);

${ }^{2}$ Hasil Analisis Proksimat di Pusat Studi Pangan dan Gizi, Universitas Gadja Mada, Yogyakarta (2017);

${ }^{3}$ Berdasarkan Carpenter dan Clegg (1956) dalam Anggorodi (1995) EM (kkal/kg) = 40,81 [0,87 (PK + 2,25+LK+BETN)+2,5]. 
Vol. 19 (1): 10-15

Tabel 2. Suhu, kelembaban dan Heat Stress Index di dalam kandang.

\begin{tabular}{|c|c|c|c|c|}
\hline \multirow{2}{*}{ Waktu } & \multicolumn{2}{|c|}{ Suhu } & \multirow{2}{*}{ RH (\%) } & \multirow{2}{*}{ HSI* } \\
\hline & ${ }^{\circ} \mathrm{C}$ & ${ }^{\circ} \mathrm{F}$ & & \\
\hline 4:00 & 23,5 & 74,4 & 54,7 & 129,1 \\
\hline $6: 00$ & 24,0 & 75,1 & 59,1 & 134,3 \\
\hline 8:00 & 27,1 & 80,8 & 68,0 & 148,8 \\
\hline 10:00 & 30,6 & 87,1 & 69,3 & 156,4 \\
\hline Rataan & 26,3 & 79,4 & 62,8 & 142,2 \\
\hline $12: 00$ & 33,1 & 91,5 & 69,4 & 161,0 \\
\hline $14: 00$ & 31,5 & 88,7 & 65,9 & 154,6 \\
\hline Rataan & 32,3 & 90,1 & 67,6 & 157,8 \\
\hline $17: 00$ & 27,9 & 82,3 & 70,8 & 153,0 \\
\hline 18:00 & 28,1 & 82,6 & 69,1 & 151,7 \\
\hline Rataan & 28,0 & 82,4 & 70,0 & 152,4 \\
\hline
\end{tabular}

Keterangan: $\left.{ }^{*}\right)$ Heat Stress Index berdasarkan ${ }^{\circ} \mathrm{F}+\% \mathrm{RH}$

Tabel 3. Suhu, kelembaban dan Heat Stress Index di luar kandang.

\begin{tabular}{|c|c|c|c|c|}
\hline \multirow{2}{*}{ Waktu } & \multicolumn{2}{|c|}{ Suhu } & \multirow{2}{*}{ RH (\%) } & \multirow{2}{*}{ HSI* } \\
\hline & ${ }^{\circ} \mathrm{C}$ & ${ }^{\circ} \mathrm{F}$ & & \\
\hline 4:00 & 24,5 & 76,1 & 55,4 & 131,5 \\
\hline $6: 00$ & 24,9 & 76,8 & 60,3 & 137,1 \\
\hline 8:00 & 28,1 & 82,6 & 68,2 & 150,7 \\
\hline 10:00 & 31,9 & 89,5 & 69,6 & 159,1 \\
\hline Rataan & 27,4 & 81,2 & 63,4 & 144,6 \\
\hline $12: 00$ & 34,0 & 93,2 & 70,0 & 163,2 \\
\hline $14: 00$ & 32,2 & 89,9 & 68,0 & 157,8 \\
\hline Rataan & 33,1 & 91,6 & 69,0 & 160,5 \\
\hline 17:00 & 28,5 & 83,3 & 71,7 & 155,0 \\
\hline 18:00 & 28,4 & 83,1 & 71,4 & 154,5 \\
\hline Rataan & 28,4 & 83,2 & 71,6 & 154,8 \\
\hline
\end{tabular}

Keterangan: *) Heat Stress Index berdasarkan ${ }^{\circ} \mathrm{F}+\% \mathrm{RH}$

sistem bilah, ukuran unit kandang $1,5 \times 0,75 \mathrm{~m}$. Pakan yang digunakan adalah pakan komersial starter dan finisher dan kandungan nutrisi pakan komersial dapat dilihat pada Tabel 1. Rancangan percobaan yang digunakan adalah Split Plot Design dengan main plot yaitu 3 taraf frekuensi pemberian pakan dan sub plot yaitu 3 taraf periodepemberian pakan dalam 4 ulangan sehingga terdapat 36 unit percobaan, tiap unit percobaan terdiri 7 ekor ayam.

Metode yang digunakan meliputi tahap persiapan, tahap perlakuan, tahap pengambilan data serta analisis data hasil penelitian. Tahap persiapan yaitu ayam dipelihara selama 12 minggu, pemberian pakan dengan point feed berdasarkan umur dan kebutuhan. Tahap perlakuan adalah frekuensi pemberian pakan (F1 = frekuensi pemberian pakan 1 kali, F2 $=$ frekuensi pemberian pakan 2 kali, F3 = frekuensi pemberian pakan 3 kali) dan periode pemberian pakan $(\mathrm{P} 1=$ periode pemberian pakan pukul 04:00 - 22.00 WIB, $\mathrm{P} 2=$ periode pemberian pakan pukul 06:00 - 22.00 WIB, P3 = periode pemberian pakan pukul 08:00 - 22.00 WIB). Tahap pengambilan data dilakukan pada umur ayam 12 minggu dengan mengambil sampel ayam buras super jantan.

Parameter yang diukur adalah bobot hidup, bobot karkas dan persentase karkas. Penelitian ini juga mengamati kondisi lingkungan meliputi suhu, kelembaban, Indeks Cekaman Panas (Heat Stress Index atau HSI).Pengukuran HSI dengan cara Heat Stress Index $={ }^{\circ} \mathrm{F}+\%$ RH dan suhu ${ }^{\circ} \mathrm{F}=(9 / 5$ $\left.\mathrm{x}^{\circ} \mathrm{C}\right)+32^{\circ} \mathrm{C}$ (Palupi, 2015). Nilai angka HSI (Heat Stress Index) yang nyaman untuk ayam adalah berkisar 105 (Molero, 2007).Data dianalisis dengan menggunakan sidik ragam dan uji $\mathrm{F}$ pada taraf 5\%. Keadaan kondisi lingkungan penelitian dapat dilihat pada Tabel 
2 dan Tabel 3.

\section{HASIL DAN PEMBAHASAN}

\section{Bobot Hidup Ayam Buras Super}

Pengaruh perlakuan terhadap bobot hidup ayam buras super umur 12 minggu dapat dilihat pada Tabel 4. Hasil penelitian menunjukkan bahwa rata-rata bobot hidup ayam buras super umur 12 minggu untuk masing-masing perlakuan berkisar $1.191,75-1.355,13$ g. Hasil penelitian tersebut menunjukkan bahwa bobot hidup tiap perlakuan lebih tinggi dibandingkan penelitian Muryanto et al. (2002) rata-rata bobot badan hidup ayam buras super umur 12 minggu 713,70 g. Kondisi lingkungan yang nyaman (Tabel 2. dan Tabel 3.) memberikan kesempatan ayam untuk memanfaatkan energi ransum untuk pertumbuhan, sehingga mampu menghasilkan bobot hidup yang lebih tinggi. Suhu lingkungan tinggi menyebabkan proses metabolisme terganggu, tetapi suhu yang nyaman dapat mendukung proses metabolisme tubuh ayam agar pada kondisi yang optimal (Abu-Dieyeh, 2006).

Hasil sidik ragam menunjukkan tidak ada pengaruh interaksi frekuensi pemberian pakan dengan periode pemberian pakan $(p>0,05)$ terhadap bobot hidup ayam, masingmasing perlakuan tidak berpengaruh nyata $(\mathrm{p}>0,05)$ terhadap bobot badan hidup ayam buras super. Hal ini dikarenakan ayam mampu mengkonsumsi dan menggunakan energi sesuai kebutuhannya pada kondisi yang nyaman (Tabel 2. dan Tabel 3.). Suhu dalam kandang yang berada pada jumlah suhu dan kelembaban berkisar 105 dapat diartikan keadaan kandang nyaman (Molero, 2007). Keadaan lingkungan yang nyaman menyebabkan penggunaan energi ransum pakan digunakan untuk pertumbuhan, apabila berada pada cekaman panas akan digunakan untuk melepas panas (Diarra dan Tabuaciri, 2014).

\section{Bobot Karkas Ayam Buras Super}

Pengaruh perlakuan frekuensi pemberian pakan dan periode pemberian pakan terhadap bobot karkas ayam buras super umur 12 minggu dapat dilihat pada Tabel 5. Hasil menunjukkan bahwa rata-rata bobot karkas ayam buras super umur 12 minggu untuk masing-masing perlakuan berkisar 730,5 $851,25 \mathrm{~g} / \mathrm{ekor}$. Hal itu menunjukkan bahwa bobot karkas ayam buras super lebih tinggi dibandingkan dengan penelitian Iskandar (2013) rata-rata dari bobot karkas ayam buras super dengan pemeliharaan intensif selama 12 minggu sebesar 611 g/ekor. Bobot karkas yang tinggi dipengaruhi oleh umur, bobot hidup ayam, keadaan lingkungan, besar dan komformasi tubuh.

Bobot karkas yang tinggi dipengaruhi oleh beberapa faktor antara lain umur, kualitas ransum, bobot hidup dan kondisi lingkungan (Tamzil et al., 2015). Ayam

Tabel 4. Rata-rata bobot hidup ayam buras super umur 12 minggu (g).

\begin{tabular}{lcccc}
\hline Perlakuan & $\mathrm{A} 1$ & $\mathrm{~A} 2$ & $\mathrm{~A} 3$ & Rata-rata \\
\hline F1 & $1.188,25$ & $1.313,63$ & $1.253,63$ & $1.251,84$ \\
F2 & $1.243,75$ & $1.325,88$ & $1.355,13$ & $1.308,25$ \\
F3 & $1.191,25$ & $1.211,13$ & $1.296,00$ & $1.232,79$ \\
\hline Rata-rata & $1.207,75$ & $1.283,55$ & $1.301,59$ & \\
\hline
\end{tabular}

Tabel 5. Rata-rata bobot karkas ayam buras super umur 12 minggu (g).

\begin{tabular}{lcccc}
\hline Perlakuan & A1 & A2 & A3 & Rata-rata \\
\hline F1 & 730,50 & 806,25 & 774,50 & 770,42 \\
F2 & 773,75 & 851,25 & 806,25 & 810,42 \\
F3 & 741,75 & 734,50 & 810,75 & 762,33 \\
\hline Rata-rata & 748,67 & 797,33 & 797,17 & \\
\hline
\end{tabular}


Vol. 19 (1): 10-15

Tabel 6. Rata-rata persentase karkas ayam buras super umur 12 minggu (\%).

\begin{tabular}{lcccc}
\hline Perlakuan & A1 & A2 & A3 & Rata-rata \\
\hline F1 & 61,37 & 61,17 & 61,69 & 61,41 \\
F2 & 62,09 & 64,15 & 59,56 & 61,93 \\
F3 & 62,43 & 60,51 & 62,69 & 61,88 \\
\hline Rata-rata & 61,96 & 61,94 & 61,32 & \\
\hline
\end{tabular}

yang terkena cekaman panas akan terganggu proses metabolisme di dalam tubuhnya yang seharusnya dipergunakan untuk membentuk jaringan tubuh, tetapi dipergunakan untuk melepaskan panas tubuhnya agar terlepas dari cekaman panas. Ayamyangberadapadakondisi lingkungan yang panas, mengakibatkan ayam terkena cekaman sehingga menurunkan laju pertumbuhan jaringan tubuh, karena energi ransum dipergunakan untuk melepaskan panas tubuhnya (Neves et al., 2014).

Hasil sidik ragam menunjukkan bahwa tidak ada pengaruh interaksi frekuensi pemberian pakan dan periode pemberian pakan $(\mathrm{p}>0,05)$ terhadap bobot karkas, dari masing-masing perlakuan juga tidak berpengaruh nyata $(p>0,05)$ terhadap bobot karkas. Hal ini dikarenakan nilai angka HSI berada dibawah 160 dan berkisar 105, sehingga ayam menggunakan energi ransum untuk membentuk jaringan tubuh pada kondisi nyaman. Pada Tabel 2. dan Tabel 3. diperlihatkan kondisi lingkungan nyaman, sehingga tidak mengganggu proses metabolisme tubuh ayam guna pertubuhan jaringan tubuh di dalam tubuh ayam. Jaringan tubuh dapat terbentuk dengan baik apabila ayam berada pada kondisi lingkungan yang nyaman, sehingga pertumbuhan dapat terjadi secara optimal (Mujahid, 2011).

\section{Persentase Karkas Ayam Buras Super}

Pengaruh perlakuan frekuensi pemberian pakan dan periode pemberian pakan terhadap persentase karkas ayam buras super umur 12 minggu dapat dilihat pada Tabel 6.

Hasil penelitian menunjukkan bahwa rata-rata persentase karkas ayam buras super umur 12 minggu masing-masing perlakuan berkisar 59,56-64,15\%. Persentase karkas yang dihasilkan lebih baik dari pada hasil penelitian Muryanto et al. (2002) rata-rata persentase karkas ayam buras super umur 12 minggu $60,05 \%$. Hal tersebut disebabkan ayam berada pada kondisi lingkungan yang nyaman (Tabel 2. dan Tabel 3.) sehingga presentase yang dihasilkan lebih tinggi. Kandungan nutrisi ransum, kondisi lingkungan, umur potong ayam, dan strain ayam dapat mempengaruhi persentase karkas yang akan dihasilkan (Suryanto et al., 2009). Persentase karkas dapat bertambah dengan seiring bertambahnya umur dari ayam (Abdullah et al., 2010).

Hasil sidik ragam menunjukkan bahwa tidak ada pengaruh interaksi frekuensi pemberian pakan dan periode pemberian pakan $(p>0,05)$ terhadap persentase karkas, dari masing-masing perlakuan juga tidak berpengaruh nyata $(p>0,05)$ terhadap persentase karkas. Hal tersebut terjadi karena ayam yang berada dikondisi nyaman, penyerapan nutrien ransum di dalam tubuh ayam akan terjadi secara optimal, sehingga mampu membentuk jaringan tubuh yang dapat mempengaruhi meningkatnya presentase karkas ayam. Aktivitas ayam dalam mengkonsumsi ransum pada kondisi lingkungan tertentu berpengaruh terhadap produksi karkas yang dicapai, karena jika suhu tinggi nafsu makan rendah akan menyebabkan laju pertumbuhan dari ayam tersebut menjadi terhambat dan akhirnya produksi karkas yang dihasilkan menjadi menurun (Mointi, 2014).

\section{KESIMPULAN}

Kesimpulan dari penelitian ini adalah tidak ada interaksi frekuensi pemberian pakan dengan periode pemberian pakan, begitu juga 
masing-masing perlakuan tidak memberikan pengaruh terhadap produksi karkas ayam buras super.

\section{DAFTAR PUSTAKA}

Abdullah, Y. A., N. A. Al-Beitawi, M. M. S. Rjoup, R. I. Qudsieh dan M. A. A. Ishmas. 2010. Growth performance, carcass and meat quality characteristic of different commercial crosses of broiler strains of chicken. Poult. Sci. 47 (1) $: 13-21$.

Abu-Dieyeh, Z. H. M. 2006. Effect of chronic heat stress and long-term feed restriction on broiler performance. J. International Poult. Sci. 5 (2) : 185 190.

Diarra, S.S. dan P. Tabuaciri. 2014. Feeding management of poultry in high environmental temperatures. J. International Poult. Sci. 13 (11) : 657 -661 .

Hasan, N. F., U. Atmomarsono dan E. Suprijatna. 2013. Pengaruh frekuensi pemberian pakan pada pembatasan pakan terhadap bobot akhir, lemak abdominal dan kadar lemak hati ayam broiler. J. Anim Agric. 2 (1) : 336 - 343.

Iskandar, S. 2013. Pertumbuhan ayam-ayam lokal sampai dengan umur 12 minggu pada pemeliharaan intensif. Prosiding Lokakarya Nasional Inovasi Teknologi Pengembangan Ayam Lokal. 9 (1) : $132: 137$.

Li, M., J. Wu dan Z. Chen. 2015. Effects of heat stress on the daily behavior of wenchang chickens. Brazilian J. of Poult. Sci. 17 (4) : 559 - 566.

Mointi, D. M. 2014. Produktivitas ayam kampung super periode starter yang diberi jenis pakan komersial. Fakultas Peternakan Universitas Negeri Gorontalo, Gorontalo. (Tesis)

Molero, C. 2007. Nutritional solutions to heat stress. International Poult. Prod. 15 (5)
: $27-29$.

Mujahid, A. 2011. Nutritional strategies to maintain efficiency and production of chickens under high environmental temperature. J. Poult. Sci. 48 : $145-$ 154.

Muryanto, P. S. Hardjosworo, R. Herman dan H. Setianto. 2002. Evaluasi karkas hasil persilagan antara ayam kampung jantan dengan ayam ras petelur betina. J. Anim Prod. 4 (2) : 71 - 76.

Neves, D. P., T. M. Banhazi dan I. A. Naas. 2014. Feeding behaviour of broiler chickens : a review on the biomechanical characteristics. J. Poult. Sci. Brazillian. $16(2): 1-16$.

Palupi, R. 2015. Manajemen mengatasi heat stess pada ayam broiler yang dipelihara dilahan kering. Prosiding Seminar Nasional Lahan Suboptimal, Palembang. Hal : $1-9$.

Suganya, T., S. Senthilkumar, K. Deepa dan R. Amutha. 2015. Nutritional management to alleviate heat stress in broiler. $\mathrm{J}$ International Environ. Technol. Sci. 4 (3) : $661-666$.

Sugito dan M. Delima. 2009. Dampak cekaman panas terhadap pertambahan bobot badan, rasio heterofil: limfosit dan suhu tubuh ayam broiler. J. Ked. Hewan. 1 (3) : 218 - 226.

Suryanto, E., H. Sasongo, Maryam dan R. Santosa. 2009. The effect of type and slaughter age on the peformances and carcass charactheristic of male Arab chicken. J. Indonesian Trop. Anim. Agric. 34 (3) : 181 - 189.

Tamzil, M. H., M. Ichsan, N. S. Jaya dan M. Taqiuddin. 2015. Growth rate, carcass weight and percentage weight of carcass parts of laying type cockerels, kampong chicken and arabic chicken in different ages. J. Nurt. Pakistan. 14 (7) : 377 - 382 . 